\title{
Clever COVID-19, Clever Citizens-98: Critical and Creative Reflections from Tehran, Toronto, and Sydney
}

\author{
Laura Bisaillon (1D) Mehdi Khosravi • \\ Bahareh Jahandoost • Linda Briskman
}

Received: 4 May 2020 / Accepted: 12 August 2020

(C) Journal of Bioethical Inquiry Pty Ltd. 2020

\begin{abstract}
Our world suffers. Some people suffer more than others. Since the first part of 2020, ours is justly described as a time of uncertainty, threat, and upheaval. In this article, we offer reflections threaded narratively, told from the specificity of our societal contexts in Iran, Canada, and Australia. What might we learn in the present and anticipated future from people living chronically within conditions of uncertainty and immobility and also those experiencing uncertainty and immobility for the first time? We argue that reflexive comparative analysis bridging social and visual analysis, anchored in embodied conditions of such people, offers a way to learn from responses to COVID-19 while also being an exercise in ethical research practice. This reflection builds on and extends from our scholarly collaborations that have been ongoing since 2015. Our title recognizes this specific virus as stealthy. Importantly, our choice of
\end{abstract}

\author{
L. Bisaillon $(\bowtie)$ \\ Department of Health and Society, University of Toronto \\ Scarborough, 1265 Military Trail, Toronto, Ontario M1C 1A4, \\ Canada \\ e-mail: Laura.bisaillon@utoronto.ca \\ M. Khosravi \\ Shahid Beheshti University of Medical Sciences, Tehran, Iran \\ e-mail: Mehdikhosravi@sbmu.ac.ir \\ B. Jahandoost \\ Tehran University of Fine Arts, Tehran, Iran \\ e-mail: b.jahandoost@gmail.com \\ L. Briskman \\ Western Sydney University, Penrith, NSW 2751, Australia \\ e-mail: briskman@westernsydney.edu.au
}

words identifies resident Iranians-whose experiences were the original impetuses for this paper, and whose lives provide its empirical basis (98 is Iran's country code) - as equally steely.

Keywords Australia $\cdot$ Canada $\cdot$ COVID-19 . Immobility · Iran · Material conditions · Movement . Social analysis $\cdot$ Social suffering $\cdot$ Visual analysis

Our world suffers. Some people suffer more than others. Since the first part of 2020, ours is justly described as a time of uncertainty, threat, and upheaval. In this article, we offer reflections threaded narratively, told from the specificity of our societal contexts in Iran, Canada, and Australia. What might we learn in the present and anticipated future from people living chronically within conditions of uncertainty and immobility and also those experiencing uncertainty and immobility for the first time? We argue that reflexive comparative analysis bridging social and visual analysis, anchored in embodied conditions of such people, offers a way to learn from responses to COVID-19 while also being an exercise in ethical research practice. This reflection builds on and extends from our scholarly collaborations that have been ongoing since 2015. Our title recognizes this specific virus as stealthy. Importantly, our choice of words identifies resident Iranians - whose experiences were the original impetuses for this paper, and whose lives provide its empirical basis (98 is Iran's country code) - as equally steely. 


\section{Springtime and Balance: Bahareh, Iran}

Iran is a land of myths and rituals. Most myths have been inscribed in Persian literature. Our central cultural celebration is Nowruz, Iranian New Year, through which we welcome spring. This ritual dates back 3,000 years. In the Shahnameh or Book of Kings, the jewel in the crown of Persian literature, ${ }^{1}$ King Jamshid of the Pishdadian dynasty calls for Nowruz to happen on the first day (Hormoz) of the first month (Farvardin) in Iran's calendar. At its heart, Nowruz is a celebration of the equilibrium between earth and nature, and this idea is central in Iranian mythology and storytelling (Bahar 2016; Joneidi 2015). After four hundred years of mending, learning, and creating, Jamshid greeted spring on Hormoz with a wish: for people to live in peace, to avoid suffering, and to harbour no resentment.

Nowruz is a celebration of community. People gather to show appreciation to God, wish for health and wealth, pray for the dead, and cook together. They also set a table, haft seen. They put seven (haft) items as symbols of sacred plants said to stimulate wellness and steadiness: airborne leaves symbolize balance, roots groundedness, and vegetation is associated with ethical properties (Ameshaspand). Such rituals have been repeated for millennia, and there are local and regional variations in the way people in Iran and its bordering countries and their diasporas enact Nowruz and the haft seen.

In 2020, Iranians needed to change how we celebrated Nowruz. The act of gathering ran the risk of imperilling life itself. This is where and when we modified traditions and gathered virtually. We struggled to reconcile ancient cultural practices with contemporary imperatives to distance. At the same time, within my extended family, we recognized these changes as ways of caring for each other and thus dovetailing with the spirit of Nowruz. Figure 1 is my screen shot of our family's haft seen: four arrangements of items, carefully curated, under separate roofs rather than one roof. This is the first time in our lives that we did not gather in person. In my role as educator and professional Naqqal, which means storyteller in Persian, I am used to directing and performing or enacting cultural rituals on stages in Iran and around the world (Bisaillon 2018b). For the purposes of our collective analysis, though, I have used my

\footnotetext{
${ }^{1}$ See http://www.bl.uk/learning/cult/inside/shahnamestories/ shahname.html
}

camera's lens, creating an assemblage of images as a means to offer the opportunity to reflect on and question how our society's cultural and religious customs postCOVID-19 will or must be modified. What will haft seen and performance rituals consist of in the wake of this disease? What I strongly suspect is that we Iranians will be faced with making all sorts of heretofore unseen shifts in the ways we carry out customary practices in private and public spheres at Nowruz and other times of the year.

\section{Limits and Learning: Mehdi, Iran}

Being deprived of formal learning during times of crisis can have long-term effects. This current moment in time shows us how the propagation of a weird and unpredictable virus disrupts people's daily routines globally.

While workers in many vocational and professional milieus are not going to their workplaces, some services continue because they are considered core social goods. One of these is formal education. E-learning becomes a valuable mode of transmitting knowledge. Can elearning meet people's learning needs and replace inperson contact partially or fully? I am a graduate student currently enrolled in courses that I take via e-learning. I am also an independent journalist and social activist living in Tehran. I have been listening attentively to debates about virtual education, all the while watching schools and universities in Iran close their doors. Elearning poses serious challenges in Iran.

The technical infrastructure needed to support elearning is not fully available to us in this country. There is unequal supply and access to the Internet, and limits to connectivity are especially pronounced in rural and remote villages. For another thing, the Iranian Internet is supplied by the state. From a security perspective, it is not possible to provide people with stable online access, since disconnections and disruption to Internet supply are common. Teachers and students have yet to receive training in the online strategies, tools, and techniques on which e-learning relies. Updated online programmes are state filtered. In practice, multinational technology companies that could provide Internet services are reluctant to do so because of international political sanctions against the Iranian state. Beyond issues of technical impediment, the domestic tools we have at our disposal have serious privacy concerns. 


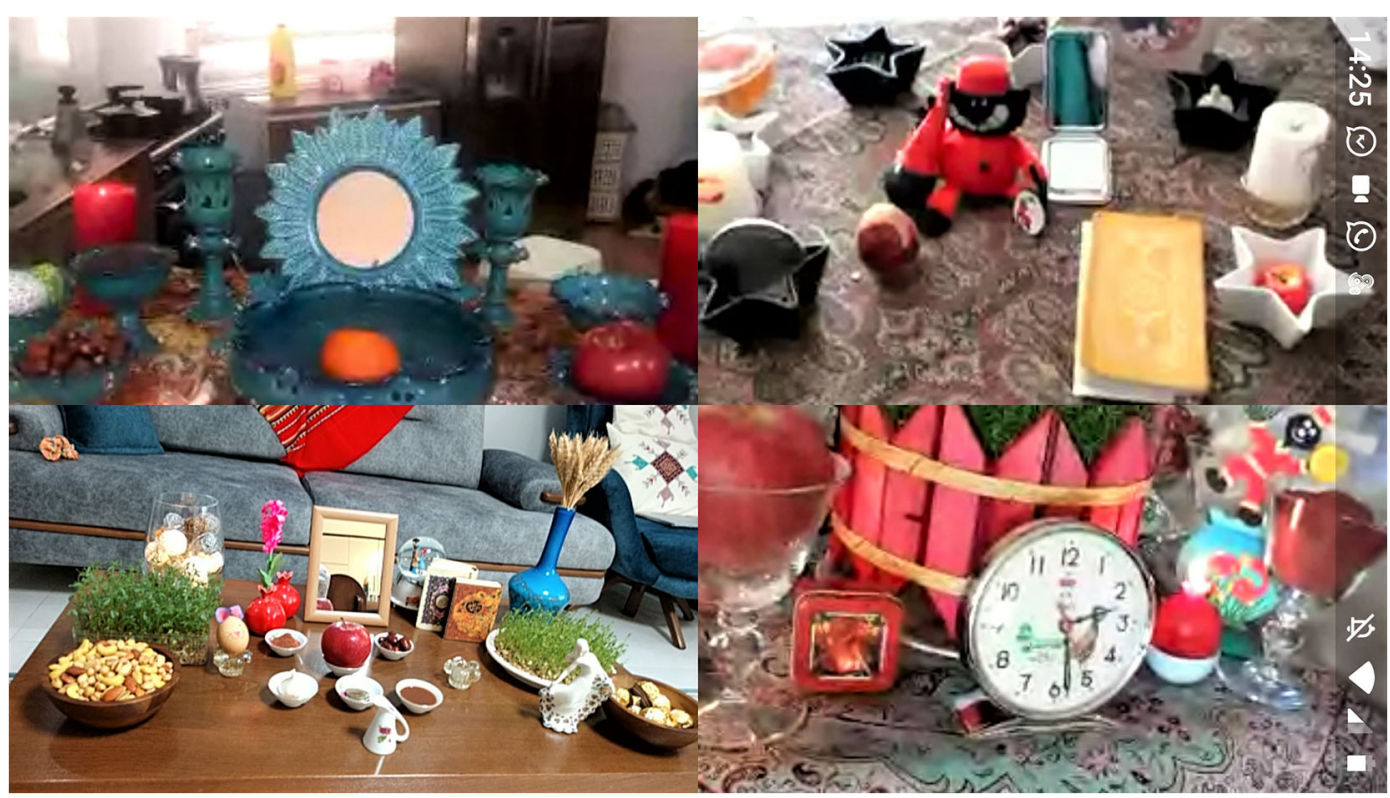

Fig. 1 Separate, but together: Changing haft seen and Nowruz practices to care for each other within conditions imposed by COVID-19

In Iran, teachers and learners alike consider screenmediated learning rather a luxury. Many resist the idea, let alone the practice, of such a shift. Recently, anticipated problems with being able to create workable and sustainable e-learning arrangements resulted in students mobilizing against the imposition or roll-out of electronic forms of teaching and learning. Frustrated, learners protested and criticized the medium. As a result, protest hashtags mushroomed throughout Iran. To illustrate this point, I took two screen shots, seen below. The first shows student slogans against the imposition of online learning (Fig. 2) and the second, state coverage of student mobilization (Fig. 3). Students designed the former as a poster, which they disseminated using social media. They specified their concerns, demanding that the state address them. Their hashtag "No Virtual Learning" went viral, as the saying goes. Their movement spread, rapidly becoming Twitter's top Persian-language trend. On the Twitter account of its news agency, the government issued an official response to the students' campaign (Fig. 3). Technical Internet problems and student and teacher inexperience with online learning systems were reasons cited for its inability to improve virtual infrastructure. In the weeks following protests, the state upgraded the online infrastructure and learning systems it makes available to students throughout the country.

Using the Internet to entertain, communicate, and engage with social media are integral parts of what many of us in Iran do every day. Much money and time are spent on these activities. Yet, there is a long way to go before virtual education is broadly accepted here. As I observe changes to dominant ways of doing things in my country, triggered by COVID-19, I see that nimbleness and experimenting with new pedagogical approaches and tools are vital. Changes to usual ways of receiving knowledge, using e-learning, and making selfeducation feasible, are important moves. I now muse about how we Iranians will rise to the challenges that such changes are imposing.

\section{Kinship and Distance: Laura, Canada}

People who have left their countries as forced migrants are always "socially distanced" from their kin. Family members have often had no choice but to fan out across the world. Meanwhile, other family members are left behind because they have no other option but to stay back.

As a sociologist and institutional ethnographer, I carry out inquiries from within routine, perhaps overlooked, and otherwise taken-for-granted practices of daily life. Grounded in the social margins, I problematize cultural, economic, and bureaucratic relations that people in these places experience as problematic.

Since the first part of 2020, my spouse and I have stayed still, steady, and sedentary. This is a new 


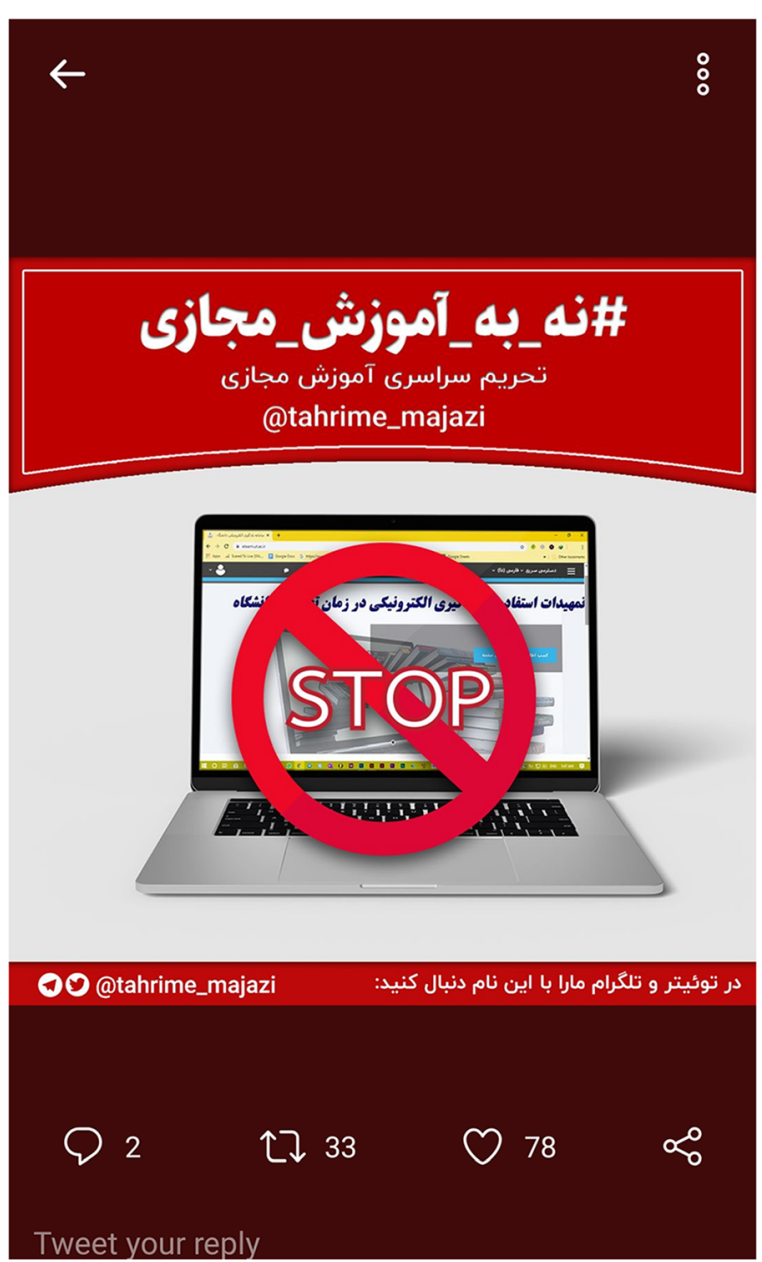

Fig. 2 Students against virtual learning: Protesting shift to online learning via Twitter, Instagram and Telegram

experience for us, who have shared a roof for more than a decade. During this time, we have listened to mainstream Canada talk and talk (since we live in societies where texting, tweeting, and talking happen tirelessly). I have paid ethnographic attention to how people I have observed in person or virtually speak about what "social distancing" entails and feels like for them. Masked pedestrians divert in half circles as they approach others on sidewalks. People have taken to referring to these practices as "a new normal." Family members unmasked see and get seen via desktop and handheld screens.

Yet when we juxtapose the mainstream's generalized angst about such temporary impositions and the impossibility of meeting and greeting in the flesh in particular, a deep divide renders: vast numbers of inhabitants across Canada have no choice but to create and

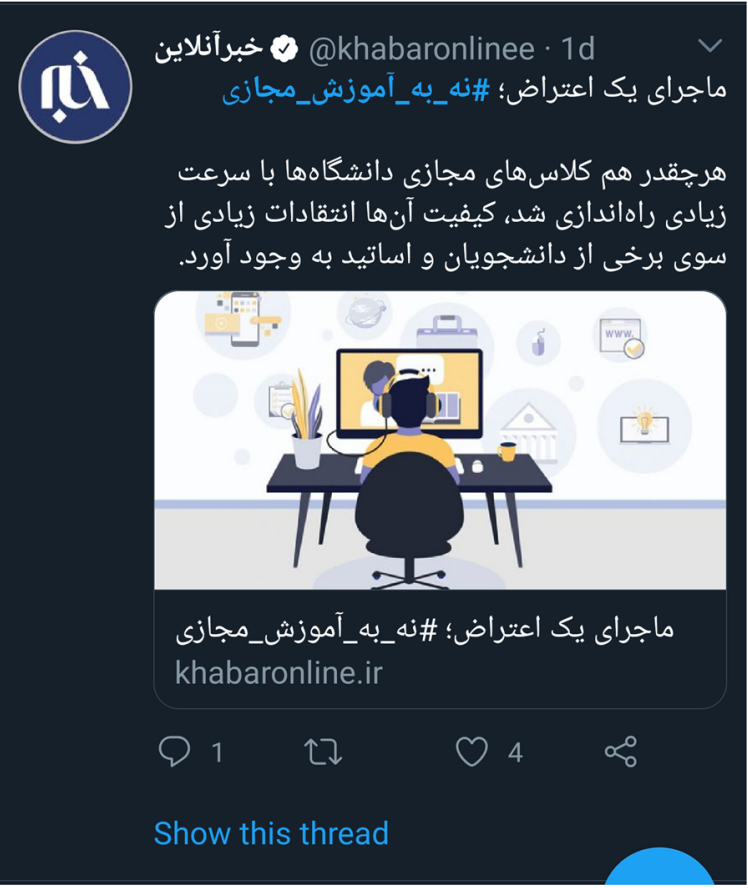

Fig. 3 The state on students against virtual learning: Upgrading online infrastructure and learning systems

participate in family life coordinated by screens permanently. I felt compelled to bring this point to life during a recent call with faraway family members (Fig. 4). My kin are people who were forced from their countries by diabolical men in military suits backed by other diabolical men in aligned and non-aligned superpower suits. They are people who spent their first decades stranded, suspended, sponsored: becoming refugees-racialized migrants, people of diaspora; being poor-scraping by, supporting faraway kin (Moussa 1993). Producing and reproducing family life deploying "social distancing" techniques are skills that former forced migrant families possess by necessity.

We all suffer from the presence and effects of COVID19. Yet, some of us suffer more than others. The origins of the suffering I evoke arise structurally and includes pains induced by health-based prejudice in immigration law carried out in state practices (Bisaillon 2018a). Some among us know uncertainty, threat, and upheaval as stable features of our lives (Albaih 2020). Mine is a call to pay ethnographic attention to teachings that our fellow inhabitants in societies whose populations increase through immigration, Canada and Australia for example, have to offer. Having endured contingency and struggle imposed by chaos, disorientation, and anxiety beyond 


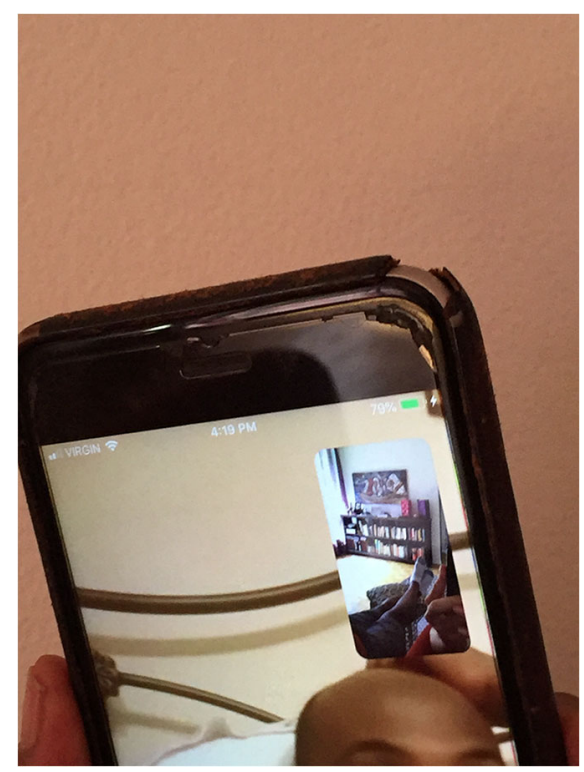

Fig. 4 Family time courtesy of FaceTime: Bridging distance between North America, Nordic nations, Western Europe and the Horn of Africa via screens

their control, forced migrants have the hard-earned expertise to help people, families, and communities brace for, adapt to, and accept the uncertainty, confusion, and arbitrariness that COVID-19 has thrusted on us and will continue to thrust on us.

\section{Privileged and Not Privileged: Linda, Australia}

Australia is the land "down under." Its location in the recesses of the southern hemisphere, however, offers minimal protection from COVID-19. Increasing international two-way travel exacerbates risk of disease spreading from person to person.

I am a human rights social worker, deeply interested in the politics of disadvantage and in traversing the boundaries between civil and political rights and economic and social rights. As a somewhat privileged observer of the pandemic, I see opportunity for reflection and activism not previously apparent. I am cautiously optimistic that the time may be ripe for overhauling dominant discourses about structural disadvantage. In so doing, I ponder the impact of the pandemic in Australia at three distinct yet interconnected levels, joined by ideas of justice and injustice: market economy, compassionate community, and citizen restrictions.
Much publicity around the impact of COVID-19 is confined to the middle classes alone - classes who have previously benefited handsomely from unfettered capitalism and rampant consumerism. But, there is a hint that reliance on the market economy is showing cracks. There is now less judgement of those experiencing unemployment, with the current conservative government bolstering social security as the previously affluent are plummeting into poverty (King 2020). My hope is for future political transformation that is attentive to seeing universal economic rights as essential to a fully functioning society.

The second relates to the rebuilding of society based on compassionate community. What are the limits, however? I use an example from my research and advocacy, namely asylum seeker detention, where neither government nor media nor community present a compassionate and human rights affirming response. Stopping asylum seeker boats has been a mantra of successive governments in Australia, a country that shamefully criminalizes and warehouses would-be immigrants who, on board boats, aim to land and remain (Briskman, Latham, and Goddard 2008). Migrants continue to be detained despite the risk of virus spread in closed environments. In an ironic turnabout since the outbreak of COVID-19, leisure-time luxury liners are now stopped and passengers detained (quarantined) for two weeks in hotels to prevent disease spread. I render this irony overt in Figure 5. I took the top image with my telephone during fieldwork. In it, we see migrant people on a boat. I have deliberately concealed their faces so we cannot identify them. Below it is a photo in the public domain: the Ruby Princess cruise ship moored in Sydney Harbour. In juxtaposing these images, I pinpoint differential treatment of arrivals at Australia's shores. In the former, people seeking state protection are rounded up, their vessel headed for an immigration detention centre, their future uncertain. In the latter, privileged passengers disembark freely. After they do, they are exposed to COVID-19, contract infection, and death follows for many. These twinned images are meant to provoke. Will complaints about containment, albeit in comfortable settings for a limited time, generate empathy for asylum seekers warehoused in prison-like settings who also, and importantly, have committed no crime?

The final area where I am less hopeful is also in the realm of civil rights. With extraordinary powers acceded 
Fig. 5 An important and ironic turnabout made visible: Treating different sorts of boat people differently as they arrive aboard different vessels in Australia (credit for bottom image: Getty Images)

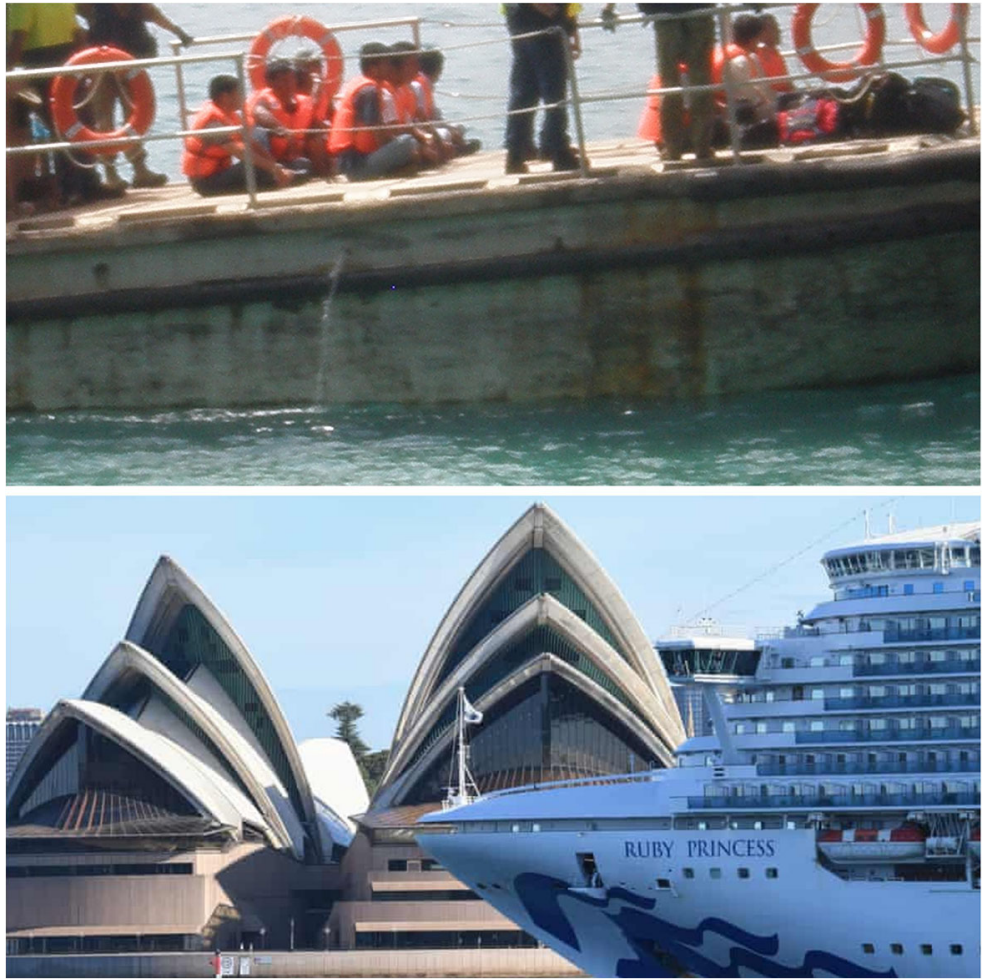

to the state in the interest of public health, can we be assured that these will be reversed in good times? We are observing a rise in neighbourhood policing to ensure social distancing rules are respected. Civil libertarians point out that targets are disadvantaged localities and over-policed groups, including Indigenous communities. Measures in some jurisdictions, such as excessive fines for minor breaches and threats of imprisonment or tagging, are being supplemented nationally with the COVIDSafe app, ${ }^{2}$ which although said to be voluntary, is underpinned by persuasive rhetoric and enacted through surveillance practices.

\section{Restore and Cooperate: Promissory Wishes from Tehran, Toronto, and Sydney}

Arising from the preliminary reflections gathered in our article, we proffer some insights into what COVID-19 may cast upon the world, drawing from distinct contexts and bearing in mind that this essay is greater than the sum of its parts.

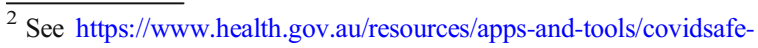
app
}

We predict lives and ways of being will be transformed post-pandemic, driven by new ways of being and relating that many of us have not previously encountered. Will Nowruz return to a continuation of its origins, or will virtual celebration of significant events, such as Easter and Passover, transmute into new relationships of restoring health and equilibrium with less travel and more inclusivity? Will the ideas that underpin education metamorphize into online dominance with current inequities being redressed across the world for people who are not the disadvantaged? Will those who have long known dislocation from family connection teach us new ways of restoring and maintaining ties of kinship? Might the isolation we all now experience lead us to become less acquisitive and more relational and cooperatively focused? In looking at possibilities, we suggest that idealism about the future be tempered with criticality, recognizing the bleak prospect that we may well just revert to the previous unequal status quo while seeing an escalation of the erosion of civil liberties for us all. 


\section{References}

Albaih, K. 2020. Your "new normal" is our "old normal." AlJazeera, April 27. https://www.aljazeera. com/indepth/opinion/normal-normal-200426164350286. html. Accessed May 1, 2020.

Bahar, M. 2016. From myth to history. Tehran: Cheshmeh Publication.

Bisaillon, L. 2018a. Finally, some changes to health-based discrimination in Canadian immigration law. The Conversation, May 13. https://theconversation.com/finally-some-changesto-health-based-discrimination-in-canadian-immigrationlaw-93340. Accessed May 1, 2020.

- 2018b. Traditional storytelling meets new media activism in Iran. The Conversation, August 23. https://theconversation.com/traditional-storytelling-meetsnew-media-activism-in-iran-93339. Accessed 1 June 2020.
Briskman, L., S. Latham, and C. Goddard. 2008. Human rights overboard: Seeking asylum in Australia. Melbourne: Scribe Publications.

Joneidi, F. 2015. Measurement in ancient Iran. Tehran: Balkh Publication.

King, M. 2020. There's new income support if you've lost work due to COVID-19. Here's who is eligible, and how to apply. Triple J Hack, March 24. https://www.abc.net. au/triplej/programs/hack/coronavirus-financial-support-whois-eligible/12083098. Accessed May 1, 2020.

Moussa, H. 1993. Storm and sanctuary: The journey of Ethiopian and Eritrean women refugees. Toronto: Artemis Enterprises.

Publisher's note Springer Nature remains neutral with regard to jurisdictional claims in published maps and institutional affiliations. 